\section{HISTORIA DE LA ARQUITECTURA PERUANA, TOMO I. ARQUITECTURA POPULAR}

\author{
JORGE BURGA \\ OFICINA EDITORIAL DE LA FACULTAD DE ARQUITECTURA, \\ URBANISMO Y ARTES DE LA UNIVERSIDAD NACIONAL DE \\ INGENIERÍA, LIMA, PERÚ, 2018 \\ RESEÑA DE DIANA RAMOS CHUQUIMIA
}

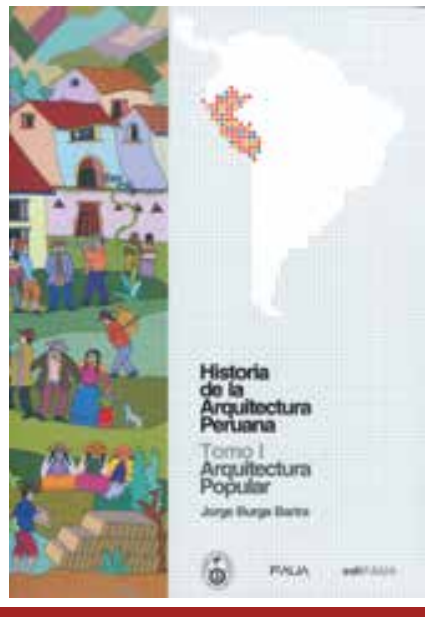

Con esta reseña se nos da la oportunidad de hablar del patrimonio en su concepción más «humilde». Valorar y revalorar el conocimiento ancestral como la tradición constructiva, aún vigente, de los pueblos antiguos de nuestro país. La mezcla de los saberes simbólicos y su diversidad tipológica en diferentes regiones geográficas hacen de la arquitectura popular el punto de partida para su estudio y análisis. El interés por el conocimiento de la arquitectura popular pasa por indagar sobre la diversidad de su contexto, el cual tiene cuatro aspectos importantes para entender la arquitectura popular: el territorio ocupado por lo popular, el temporal visto como el surgimiento y el devenir, el socioeconómico respecto de las jerarquías sociales y el simbólico que se ocupa de los factores culturales. Finalmente, explica su posición con respecto a la situación actual de la arquitectura popular y la importancia de la intervención profesional para su revalorización.

La virtud de la publicación radica en la identificación del origen del hábitat popular procedente de lo rural y su «metamorfosis» hasta alcanzar el suelo urbano de las grandes ciudades. Pasa por la descripción del origen cosmogónico del hombre andino, inmerso en su tradición constructiva integrada en el diverso y agreste territorio del ande, la chala y la selva, y su relación con las creencias más profundas nacidas de la tierra. Describe el origen de la construcción popular vinculada íntimamente al rito, a su vínculo con los grupos sociales y su entorno. A diferencia de otros autores que solo toman en cuenta lo tangible y lo material de las construcciones, Burga opta por una visión más humanista, la dimenmedioambiente, el clima y los materiales locales, que ha recogido en cada uno de sus viajes del norte, centro y sur del Perú profundo. Las experiencias del autor, con las que va nutriendo su conocimiento sobre la arquitectura vernácula y la vivienda popular, han sido plasmadas mediante bellas ilustraciones - producto de cada uno de sus viajes - en todas las páginas del libro.

Burga también hace un análisis prospectivo de las distintas expresiones regionales de la arquitectura popular, donde propone una visión panorámica del estado actual de la arquitectura vernácula en contraste con lo popular moderno de la arquitectura chicha y el amenazante auge que esta ha adquirido en las últimas décadas, así como las propuestas generadas por arquitectos contemporáneos que observan, estudian con rigor y se inspiran en la edilicia popular. Los viajes y experiencias que el autor recoge nacen de la mirada de un amante de la naturalidad y simpleza de la construcción vernácula popular, que merece ser reconocida y salvaguardada como un producto de la identidad cultural y la vivencia del hombre peruano y su relación con su hábitat a lo largo de su historia.

El libro Historia de la arquitectura peruana. Tomo I: Arquitectura popular fue presentado en diciembre del 2018, en la sede del Colegio de Arquitectos del Perú, en la ciudad de Lima. Este libro procede de la casa editorial ediFAUA de la Facultad de Arquitectura y Artes de la Universidad Nacional de Ingeniería, obra del arquitecto investigador Jorge sión sociocultural, los conceptos de
Burga Bartra, quien estuvo acompañado por varios colegas y expertos en temas de arquitectura.

El tomo I del libro se divide en seis capítulos, el primero se concentra en «El contexto», el ámbito popular, el aspecto espacial y el temporal, la ruptura y la continuidad tras la llegada de los colonizadores, el aspecto socioeconómico popular, el simbólico y los problemas de la identidad en la arquitectura. En el segundo capítulo, «Lo popular», se desarrolla la arquitectura peruana desde la conciencia y realidad de lo popular en la arquitectura, cambios en la vivienda de la ciudad globalizada, específicamente en Lima: las urbanizaciones populares. El tercer capítulo, «Lo vernáculo», consta de la arquitectura vernácula popular, la arquitectura vernácula peruana, los contextos vernáculos, los tipos vernáculos, los complementos vernáculos, la obrería o claustro del fundador. En el cuarto capítulo, «La arquitectura chicha», se exponen los orígenes de la chicha, la chicha en la arquitectura, los lugares de epicentro de la arquitectura chicha, lo vernáculo y lo chicha. El quinto capítulo, «Lo contemporáneo conceptual», aborda lo popular culto: una alternativa entre lo vernáculo y lo chicha, y el desarrollo de lo popular culto. Por último, en el sexto capítulo se presentan las conclusiones finales.

Esta publicación es una compilación detallada y más concienzuda de los libros anteriores del mismo autor. El libro en sí mismo es un testimonio transmisor de la tradición proyectual de la historia de la arquitectura peruana hasta nuestros días; recoge el alma de la arquitectura popular peruana como ningún otro trabajo de esta temática. Es una herramienta que pretende revalorar la construcción popular ampliando conocimientos y experiencia. 